Marta Sobczuk

Katolicki Uniwersytet Lubelski Jana Pawła II

\title{
ENERGETYKA JĄDROWA JAKO PRZEJAW REALIZACJI ZASADY ZRÓWNOWAŻONEGO ROZWOJU
}

\section{Wprowadzenie}

Zgodnie z założeniem dokumentu końcowego Konferencji Narodów Zjednoczonych w sprawie Zrównoważonego Rozwoju RIO+20, która odbyła się w dniach 20-22 czerwca 2012 r., energia odgrywa krytyczną rolę w procesie rozwoju, ponieważ dostęp do zrównoważonych nowoczesnych usług energetycznych:

- przyczynia się do eliminacji ubóstwa,

- ratuje życie, zapewnia poprawę zdrowia,

- pomaga w zaspokojeniu podstawowych potrzeb ludzkich. ${ }^{1}$

Rzeczywiście energetyka to jedna z najważniejszych gałęzi gospodarki. Od niej zależy rozwój pozostałych sfer życia ludzkiego. Współczesny człowiek jest uzależniony od różnego rodzaju energii i nie wyobraża sobie bez niej życia. Niestety, większość ze źródeł energii ma charakter wyczerpywalny, albo bardzo szkodliwy dla środowiska, a najczęściej posiada obie te cechy. ${ }^{2}$ Wobec czego człowiek staje przed problemem: żyć wygodnie czy oszczędnie?

Zwolennicy wzmożonej ochrony środowiska odpowiedzą na to pytanie: oszczędnie, bo należy szanować zasoby naturalne i unikać nadmiernej ich degradacji. Ziemia nie służy tylko nam i należy zachować ją w jak najlepszym stanie dla przyszłych pokoleń. Natomiast zwolennicy konsumpcyjnego stylu życia stwierdzą, że nie warto żyć oszczędnie. Liczy się tylko to, co tu i teraz. Zasobów środowiska dla nas wystarczy.

Wydaje się, że te dwie koncepcje są nie do pogodzenia. Sposobem pogodzenia tych dwóch różnych stylów życia jest zrównoważony rozwój i wprowadzanie alter-

Dokument końcowy Konferencji „Przyszłość jakiej chcemy”, publ. A-CONF.216-L.1.

Podstawowymi najczęściej wykorzystywanymi i wyczerpywalnymi źródłami energii są: gaz ziemny, ropa naftowa oraz węgiel. 
natywnych źródeł energii, co pozwoli na poszanowanie środowiska z jednoczesnym swobodnym wykorzystywaniem energii.

\section{Energia w dokumencie „Przyszłość jakiej chcemy”}

Kluczowe znaczenie energii dla życia ludzkiego zostało podkreślone na początku opracowania. Autorzy dokumentu zwrócili uwagę na rolę energii w integracji społecznej i równości płci, a także na jej niezbędność w procesie produkcji.

Konferencja Rio +20 w kontekście energetyki kojarzy się przede wszystkim z tzw. zieloną energią, czyli inwestycją w odnawialne źródła energii. Rzeczywiście w omawianym dokumencie pokonferencyjnym autorzy wyrazili swoje poparcie dla zwiększonego wykorzystania odnawialnych źródeł energii i innych technologii niskoemisyjnych, bardziej efektywnego wykorzystania energii i racjonalnego wykorzystywania konwencjonalnych źródeł energii. Jednocześnie została podkreślona konieczność inwestowania w zaawansowane i czystsze technologie energetyczne. Zwrócono także uwagę na konieczność doboru źródeł energetycznych przyczyniających się do ograniczania niekorzystnych zmian klimatycznych. ${ }^{3}$

W dalszej części opracowania Autorka postara się wykazać, że większość postulatów wymienionych w dokumencie „Przyszłość jakiej chcemy” jest możliwa do zrealizowania, dzięki wykorzystaniu w omawianym sektorze gospodarki energii jądrowej.

\section{Założenia zasady zrównoważonego rozwoju}

Koncepcja zrównoważonego rozwoju została sprecyzowana w 1987 r. w Raporcie Brundtland. ${ }^{4}$ Komisja określiła omawiane pojęcie jako „rozwój, który zapewnia zaspokojenie potrzeb obecnych pokoleń, nie przekreślając możliwości zaspokojenia potrzeb pokoleń następnych". ${ }^{5}$ Rozwój ten odnosi się do aspektów środowiskowych, gospodarczych i społecznych. ${ }^{6}$ Zrównoważony rozwój był tematem wielu późniejszych dyskusji, a przede wszystkim ideą przewodnią trzech międzynarodowych konferencji:

- Szczytu Ziemi w Rio de Janeiro w 1992 r.;

- Światowego Szczytu Zrównoważonego Rozwoju w Johannesburgu w 2002 r.;

- Konferencji Rio+20 w Rio de Janeiro w 2012 r.

Szerzej na temat energii zobacz dokument „Przyszłość jakiej chcemy” pkt. 125-129.

Tekst raportu dostępny na stronie internetowej: http://www.un.org/documents/ga/res/42/ares42-187.htm

L. Pawłowski, Rola monitoringu środowiska w realizacji zrównoważonego rozwoju, „Rocznik Ochrona Środowiska" 2011, t. 13, s. 333.

6 E. Czarski (red.), Wskaźniki zrównoważonego rozwoju Polski, Katowice 2011, s. 5. 
Każda z tych konferencji przyczyniła się do dokładniejszego zrozumienia pojęcia zrównoważonego rozwoju oraz tworzenia celów, do których miały prowadzić poczynania ludzkości. ${ }^{7}$

Zasada zrównoważonego rozwoju została inkorporowana do polskiego porządku prawnego przepisami ustawy zasadniczej ${ }^{8}$ oraz ustawy z dnia 27 kwietnia 2001 r. - Prawo ochrony środowiska (tekst jedn. Dz.U. z 2008 r. Nr 25, poz. 150 z późn. zm.). Zasada zrównoważonego rozwoju została podniesiona do rangi zasady konstytucyjnej. W art. 5 Konstytucji zapewniono, że Rzeczpospolita Polska strzeże niepodległości i nienaruszalności swojego terytorium, zapewnia wolności i prawa człowieka i obywatela oraz bezpieczeństwo obywateli, strzeże dziedzictwa narodowego oraz zapewnia ochronę środowiska, kierując się zasadą zrównoważonego rozwoju. Definicję legalną zrównoważonego rozwoju zawiera art. 3 p.o.ś. Zgodnie z tą definicją przez zrównoważony rozwój rozumie się taki rozwój społeczno-gospodarczy, w którym następuje proces integrowania działań politycznych, gospodarczych i społecznych, z zachowaniem równowagi przyrodniczej oraz trwałości podstawowych procesów przyrodniczych, w celu zagwarantowania możliwości zaspokajania podstawowych potrzeb poszczególnych społeczności lub obywateli zarówno współczesnego pokolenia, jak i przyszłych pokoleń. ${ }^{9}$

Zasada zrównoważonego rozwoju nakazuje integrowanie działań politycznych, społecznych i ekonomicznych z ochroną środowiska.

W oparciu o elementy definicji legalnej zostanie omówiona kwestia wpływu energetyki jądrowej na założenia zrównoważonego rozwoju.

\section{Zrównoważony rozwój w energetyce}

Zrównoważony rozwój w energetyce ma na celu przede wszystkim takie uzyskiwanie energii, które jak najmniej szkodzi środowisku. Jednocześnie należy zapewnić bezpieczeństwo energetyczne, czyli pewność i różnorodność energii po racjonalnej cenie.

System energetyczny można uznać za zrównoważony, jeżeli spełnia następujące warunki:

- wykorzystuje różnorodne źródła pozyskiwania energii;

- energia wytwarzana i dostarczana jest w sposób jak najmniej szkodliwy dla środowiska;

- energia jest wytwarzana i dostarczana po racjonalnych kosztach;

- zużycie zasobów naturalnych jest minimalne;

7 Szerzej na temat zrównoważonego rozwoju zob.: D. Liszewski, Etyczne podstawy rozwoju zrównoważonego, „Problemy Ekorozwoju” 2007, vol. 2, nr 1, s. 27 i n.

$8 \quad$ Konstytucja Rzeczypospolitej Polskiej z dnia 2 kwietnia 1997 r. (Dz.U. Nr 78, poz. 483 z późn.zm.).

9 Szerzej na temat zasady zrównoważonego rozwoju: A. Haładyj, Prawo ochrony środowiska, [w:] S. Wrzosek (red.), Kompendium wiedzy administratywisty, Lublin 2008, s. 415. 
- sposób wytwarzania i dostarczania energii jest bezpieczny dla zdrowia ludzi i zwierząt. ${ }^{10}$

Warto zauważyć, że wymienione powyżej cechy systemu energetycznego są zbieżne z wymogami dotyczącymi zapewnienia bezpieczeństwa energetycznego. ${ }^{11}$

Aby odpowiedzieć na pytanie, czy energetyka jądrowa spełnia te wymagania, należy zwrócić uwagę na trzy aspekty: ekologiczny, ekonomiczny oraz społeczny.

\section{Aspekty ekologiczne energetyki jądrowej}

Aspektu ekologicznego energetyki jądrowej nie można określić jednoznacznie. W tym względzie energetyka jądrowa ma zarówno wady, jak i zalety.

Zaletą energetyki jądrowej jest niskoemisyjność dwutlenku węgla i gazów cieplarnianych. ${ }^{12}$ Pod tym względem energetyka jądrowa jest obok odnawialnych źródeł energii najbezpieczniejszą formą pozyskiwania energii. Ten walor energetyki jądrowej ma również bardzo duże znaczenie ze względu na wypełnienie zobowiązań Polski wynikających z pakietu klimatyczno-energetycznego. ${ }^{13}$

Ponadto energetyka jądrowa charakteryzuje się praktycznie zerowym wykorzystywaniem zasobów naturalnych w procesie wytwarzania energii. ${ }^{14}$ Tylko w niewielkim stopniu ulegają eksploatacji zasoby wodne, wykorzystywane do chłodzenia reaktora. $^{15}$

Energetyka jądrowa w aspekcie ekologicznym ma bardzo poważną wadę, którą jest problem składowania odpadów radioaktywnych. W doktrynie szacuje się, że odpady radioaktywne wymagają kontroli i przechowywania w specjalnych beczkach w restrykcyjnych warunkach nawet do 1000 lat. ${ }^{16}$ Obawy dotyczące wysokich dawek promieniowania oraz trwałości materiału, z którego wykonane miałyby być pojemniki na zużyte paliwo, wydają się w pełni uzasadnione. Jest to niewątpliwie bardzo poważny problem, a jednocześnie mocny argument przeciwników atomów w walce z planami budowy elektrowni jądrowej w Polsce.

\footnotetext{
10 Zob. szerzej: D. Grodzicka-Kozak, H. Okuniewska, P. Górska, Energetyka jądrowa a zrównoważony rozwój w Polsce, [w:] K. Jeleń, Z. Rau (red.), Energetyka jądrowa w Polsce, Warszawa 2012, s. 834 i n.

Por. M. Nowacki, Prawne aspekty bezpieczeństwa energetycznego w UE, Warszawa 2010, s. 46 i n.

Zalety energetyki jądrowej omawia: K. Borowski, Energetyka jądrowa - perspektywy rozwoju w Polsce, „Infos” 2007, nr 10, s. 1 in.

Zob. http://ec.europa.eu/energy/publications/doc/2011_energy2020_en.pdf

A. Strupczewski, Nie bójmy się energetyki jądrowej!, Warszawa $200 \overline{9}$, s. 10 i n.

Zob. szerzej: K. Rzymkowski, Energetyka jądrowa i środowisko, „Postępy techniki jądrowej” 2010, vol. 53, z. 3, s. $10 \mathrm{in}$.

16 K. Borowski, Energetyka jądrowa..., op. cit., s. 1.
} 


\section{Aspekty ekonomiczne energetyki jądrowej}

Podobnie jak w powyższym przypadku aspekt ekonomiczny energetyki jądrowej można rozpatrywać na poziomie wad i zalet. W przypadku kwestii ekonomicznych wady można zaobserwować na etapie inwestycyjnym, natomiast zalety na poziomie wykorzystywania energii z wybudowanych już elektrowni.

Etap inwestycyjny w zakresie budowy obiektów energetyki jądrowej charakteryzuje się bardzo wysokimi kosztami. Koszty te obejmują budowę i sprowadzenie reaktora, wyszkolenie lub pozyskanie zagranicznych kadr specjalizujących się w energetyce jądrowej, uzyskanie wielu pozwoleń i specjalistycznych ekspertyz. Wszystko to wymaga ogromnych nakładów finansowych.

Natomiast $\mathrm{z}$ drugiej strony podkreśla się, że energia jądrowa jest najbardziej stabilnym i najtańszym źródłem energii elektrycznej. Jak wynika z badań specjalistów, ${ }^{17}$ łączne koszty pracy elektrowni jądrowej w 2011 r. wynosiły średnio prawie 22 dolary/ MWh, podczas gdy koszty energii z OZE w tym samym roku wahały się od prawie 27 do 45 dolarów/ MWh w różnych krajach. Ponadto wskazuje się na stabilizację cen uranu. ${ }^{18} \mathrm{~W}$ tym kontekście warto również wspomnieć o kwestii politycznej, jaką jest uniezależnienie się od monopolistów konwencjonalnych źródeł energii.

\section{Aspekty społeczne energetyki jądrowej}

Kwestie społeczne dotyczące energetyki jądrowej są najtrudniejsze do rozstrzygnięcia. Problem inwestowania w rozwój energetyki jądrowej wyraźnie dzieli społeczeństwo. $Z$ jednej strony podkreśla się pozytywy z zakresu ekologii i ekonomii. Przekonuje się społeczeństwo o braku zagrożeń dla istot żywych w przypadku małych dawek promieniowania.

$\mathrm{Z}$ drugiej strony przeciwnicy energii $\mathrm{z}$ atomu przytaczają przykłady chorób i zgonów spowodowanych awariami w Czarnobylu i Fukushimie. Na wielu fotografiach i w wielu relacjach telewizyjnych można zobaczyć straszliwe skutki choroby popromiennej oraz niekontrolowane zmiany genetyczne.

Społeczeństwo boi się energii jądrowej, ale z drugiej strony czeka na źródło energii racjonalizujące koszty pozyskiwania energii. Problem energetyki jądrowej w tej kwestii jest bardzo trudny do rozstrzygnięcia, bo każda ze stron sporu wysuwa bardzo racjonalne argumenty.

\footnotetext{
17 A. Strupczewski, Niestety OZE są drogie..., „Energetyka Cieplna i Zawodowa” 2013, nr 3. Artykuł dostępny na stronie internetowej: http://www.energetyka-jadrowa.cire.pl/pokaz-pdf\%252Fpliki\%252F2\%252FNiestety_ OZE_drogie_zm.pdf

18 O kosztach energetyki jądrowej zob. także: H. Trojanowska, Bezpieczeństwo energetyczne - znaczenie energetyki jądrowej, [w:] M. Swora (red.), W kierunku nowoczesnej polityki energetycznej. Energia elektryczna, Warszawa 2011, s. 40 i n.
} 


\section{Podsumowanie}

Na podstawie przytoczonych przykładów można wysnuć wniosek, że energia jądrowa jest przejawem realizacji zrównoważonego rozwoju w sektorze energetycznym.

Po pierwsze ze względu na niskoemisyjność gazów cieplarnianych i minimalne wykorzystanie nieodnawialnych zasobów naturalnych.

Po drugie spełnia postulat racjonalności kosztów i stałości dostaw. Koszty wytworzenia i przesyłania energii są stosunkowo niskie.

W przypadku braku szkodliwości wytwarzania tego typu energii dla istot żywych trudno ocenić to jednoznacznie. Podkreśla się, że nowoczesne reaktory są praktycznie bezawaryjne, ale istnieje obawa o bezpieczeństwo tego typu obiektów w przypadku klęsk żywiołowych czy ataków zbrojnych.

Finalnie należy stwierdzić, że energetyka jądrowa wpisuje się w postulaty zrównoważonego rozwoju, ponieważ dzięki niskoemisyjności i oszczędności pozostałych zasobów pozwoli na utrzymanie stanu naszej planety na dobrym poziomie dla przyszłych pokoleń.

Trzeba natomiast zauważyć, że żadne źródło energii nie jest w stanie pokryć zapotrzebowania na nią w stu procentach. Najbardziej racjonalnym i przyjaznym dla środowiska sposobem jest wykorzystanie wszystkich źródeł energii w umiarkowanych ilościach, ponieważ żadne z nich nie może samodzielnie zapewnić odpowiedniej ilości energii bez zbytniej eksploatacji środowiska.

\section{BIBLIOGRAFIA}

Borowski K., Energetyka jądrowa - perspektywy rozwoju w Polsce, „Infos” 2007, nr 10.

Czarski E. (red.), Wskaźniki zrównoważonego rozwoju Polski, Katowice 2011.

Dokument końcowy Konferencji „Przyszłość jakiej chcemy”, publ. A-CONF.216-L.1.

Grodzicka-Kozak D., Okuniewska H., Górska P., Energetyka jądrowa a zrównoważony rozwój w Polsce, [w:] K. Jeleń, Z. Rau (red.), Energetyka jądrowa w Polsce, Warszawa 2012.

Haładyj A., Prawo ochrony środowiska, [w:] S. Wrzosek (red.), Kompendium wiedzy administratywisty, Lublin 2008.

Liszewski D., Etyczne podstawy rozwoju zrównoważonego, „Problemy Ekorozwoju” 2007, vol. 2, nr 1.

Nowacki M., Prawne aspekty bezpieczeństwa energetycznego w UE, Warszawa 2010.

Pawłowski L., Rola monitoringu środowiska w realizacji zrównoważonego rozwoju, „Rocznik Ochrona Środowiska” 2011, t. 13.

Rzymkowski K., Energetyka jądrowa i środowisko, „Postępy techniki jądrowej” 2010, vol. 53, z. 3.

Strupczewski A., Nie bójmy się energetyki jądrowej!, Warszawa 2009.

Strupczewski A., Niestety OZE są drogie..., „Energetyka Cieplna i Zawodowa” 2013, nr 3. 
Energetyka jądrowa jako przejaw realizacji zasady zrównoważonego rozwoju

Trojanowska H., Bezpieczeństwo energetyczne - znaczenie energetyki jądrowej, [w:] M. Swora (red.), W kierunku nowoczesnej polityki energetycznej. Energia elektryczna, Warszawa 2011. 


\section{NUCLEAR POWER AS A MANIFESTATION OF REALIZING} THE PRINCIPLE OF SUSTAINABLE DEVELOPMENT

The article addresses the problems associated with the impact of nuclear energy on realizing the principle of sustainable development. It describes a conception of the principle of sustainable development and goes on to present its importance in the context of energy resources. The environmental, economic and social aspects of nuclear energy is also analyzed. The object of the study is to answer the question of whether nuclear power fits within the concept of sustainable development.

Keywords: nuclear power, sustainable development, realizing, principle 